\title{
Implementation of Simple Additive Weighting (SAW) Method and Profile Matching for Employee Selection
}

\author{
Andi Pratomo Wiyono \\ Dept. of Electrical Engineering \\ Universitas Brawijaya \\ Malang, Indonesia
}

\author{
Muhammad Aziz Muslim \\ Dept. of Electrical Engineering \\ Universitas Brawijaya \\ Malang, Indonesia
}

\author{
Muhammad Aswin \\ Dept. of Electrical Engineering \\ Universitas Brawijaya \\ Malang, Indonesia
}

\begin{abstract}
Employees are an important element in a company that determines the progress of a company. With good quality employees in a company, it is easier to achieve desired goals of a company. Conventional (manual) recruitment method is vulnerable to non-technical factors such as frequent duplicate data or invalid data. In such condition, a Decision Support System (DSS) will be helpful in making decision process valid and reliable. In this paper, a Simple Addictive Weighting (SAW) method and Profile Matching were proposed to solve employee selection problem. This research was conducted at UPT Career Development and Entrepreneurship Universitas Brawijaya Malang, using data collected from written test selection in 2019. The effectiveness of both methods is analyzed by means of confusion matrix. SAW method give Accuracy rate of $94.7 \%$, Precision rate of $87.5 \%$, Recall rate of $91.3 \%$ and F-measure rate of $89.4 \%$. On the other hand, Profile Matching method obtained the Accuracy rate of $90.4 .7 \%$, Precision rate of $81.4 \%$, Recall rate of $81.4 \%$ and F-measure rate of $81.4 \%$. From these results, it can be concluded that both methods have a high accuracy value accompanied by a high precision value when used for the selection process. This system can also reduce the bias of the same data very well, as can be seen from the high Recall and F-measure rates.
\end{abstract}

Keywords: decision support system, employee selection, simple additive weighting method, profile matching, confusion matrix.

\section{INTRODUCTION}

Employees are an important element in a company in determining the progress of a company. With good quality employees in a company, it makes easier for the company to achieve the goals of a company. Selection of effective applicants or employee candidates to assess technical abilities, education, work experience as well as psychological assessments of applicants, psychological tests will generally show a person's emotional state, in addition, a technical ability test will show a person's competence to work. However, someone with good technical skills, if not supported by sufficient emotional intelligence, will experience difficulties in his work environment [1].

At present, the method used in the employee selection process at the Career Center of Universitas Brawijaya Malang (UPKK) is still using conventional methods, by using human labor in the process of determining whether or not applicants will qualify. This method is vulnerable to non-technical factors such as frequent duplicate data or invalid data. To solve this problem, the right Decision Support System is needed in determining decision making. There are various kinds of decision support system methods, namely: AHP, WP, TOPSIS, Simple Addictive Weighting (SAW), Profile Matching, expert systems and simple linear regression. Of all the decision support system methods above, the method chosen in determining the decision to acquire new employees is Profile Matching and SAW [2].

The SAW method is a systematic method of decision making that is able to show assessing the competence of applicant according to the criteria set by the company or decision maker based on systematic data analysis [3] while the Profile Matching Method is a method that compares competencies owned by the candidate and the competency of the position. So that it can be seen that the difference in competence is also often referred to as a gap. The smaller the gap (difference) a candidate gets, the candidate has a greater final score and is very close to the required qualifications [4].

Based on the description of the above problems, regarding the needs of the UPKK regarding a decision support system to assist in the selection of recruitment for employees of a company in recruiting, comparing the results of the process using the Simple Addictive Weighting (SAW) method and the Profile Matching method is an interesting thing. The application of this method is in the employee candidate selection system in UPKK so that it can help to see the potential of prospective employees to occupy a certain position in a certain institution in the company.

\section{LITERATURE REVIEW}

In 2016, M. Isman conducted research using SAW to support employee selection decisions at PT Philips Seafood Indonesia. The results of this study indicate the highest value is 77.5 with a range of 0-100. Manual calculations and calculations using a decision support system are claimed to get the similar results so that the system has high validity [5]. In other studies, using a similar method, it is said that the results of the 30-applicant data used get the comparison between manual and system calculations that have an accuracy of $81 \%$ [6].

Several other studies that have been carried out using the Profile Matching method, namely supporting sorting decisions based on the type of voice of the new members of the BIOS choir division studied by Syah in 2017. The results show that the system performance he designed can be used to make member admission decisions with the output in the form order based on the highest to the lowest end with the number of test data as much as 61 , has a validity percentage of $77.04 \%$. In fact, other studies have shown an accuracy of $96.2 \%$ [7] [8].

Based on some of the studies that have been described, it can be seen that the use of the Simple Additive Weighting and Profile 
Matching methods has satisfactory results in each method. This research will deal with the application and accuracy comparison of the Simple Additive Weighting and Profile Matching methods, with the case study of selection of prospective employees based on data held by UPKK Universitas Brawijaya.

\subsection{Decision Support System}

Michael S. Scott Morton (1970) first articulated the important concept of a Decision Support System (DSS). Michael S. Scott Morton defines DSS as an interactive computer-based system, which helps decision makers to use data and various models to solve unstructured problems.

The concept of DSS is characterized by a computer-based interactive system that helps decision making utilizing data and models to solve unstructured problems. Basically, the DSS is designed to support all stages of decision making starting from identifying problems, selecting relevant data, determining the approach used in the decision-making process, to evaluating alternative choices [9].

\subsection{Simple Additive Weighting (SAW)}

Simple Additive Weighting is a method that is often used for decision making because this method is more efficient and has a fairly high accuracy. This method uses the largest (selected) result as its output. In the Simple Additive Weighting method, there are 2 types of criteria, namely the criteria that are beneficial (benefit) and criteria that are detrimental (cost). The advantages of this method in the form of the ability to assess more accurately because it is based on the value of the criteria and weighting preferences are predetermined and can choose the best alternative from a number of alternatives, other than that due to the increase in the after determining the weight values for each attribute [10].

\subsection{Profile Matching}

Profile Matching is a method where this method first determines the competency value (ability) required for a position. The competence of these abilities must be met by the holder or the candidate whose performance will be assessed. Broadly speaking, Profile Matching is a comparison process between individual competencies and job competencies so that the difference in competence is known as a gap, and the smaller the gap resulting from the comparison process above, the greater the weight value. This means that they have a greater chance of becoming an employee candidate to occupy the position [11].

In other literature, it is stated that the Profile Matching method is a decision-making mechanism by assuming that there is an ideal predictor variable level that must be met or passed. In Profile Matching, identification of good or bad groups of employees or job applicants. The employees in the group are measured using several assessment criteria. In Profile Matching, the job applicants who are appointed are those who are closest to the ideal profile of a successful employee [4].

\subsection{The application of DSS uses SAW and Profile Matching}

The concept of DSS (as shown in Figure 1) is characterized by a computer-based interactive system that helps decision making utilizing data and models to solve existing problems.

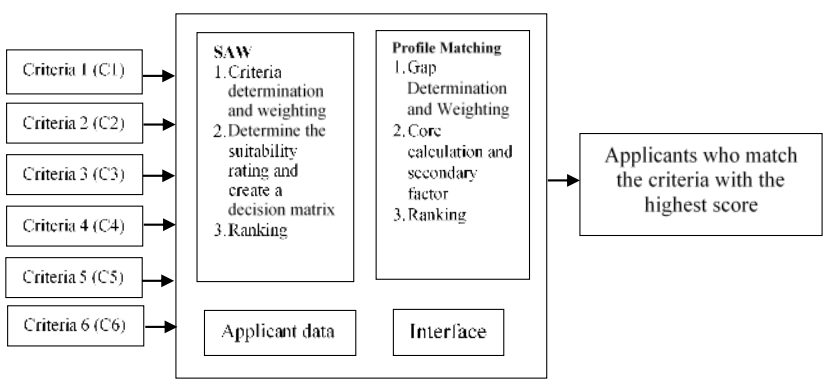

Figure 1. Application of SAW and Profile Matching in DSS

\section{STUDY DESIGN AND METHODOLOGY}

The method used in this research is data collection, design, implementation, testing and analysis as well as drawing conclusions and suggestions. Figure 2 shows the research methodology carried out in this research.

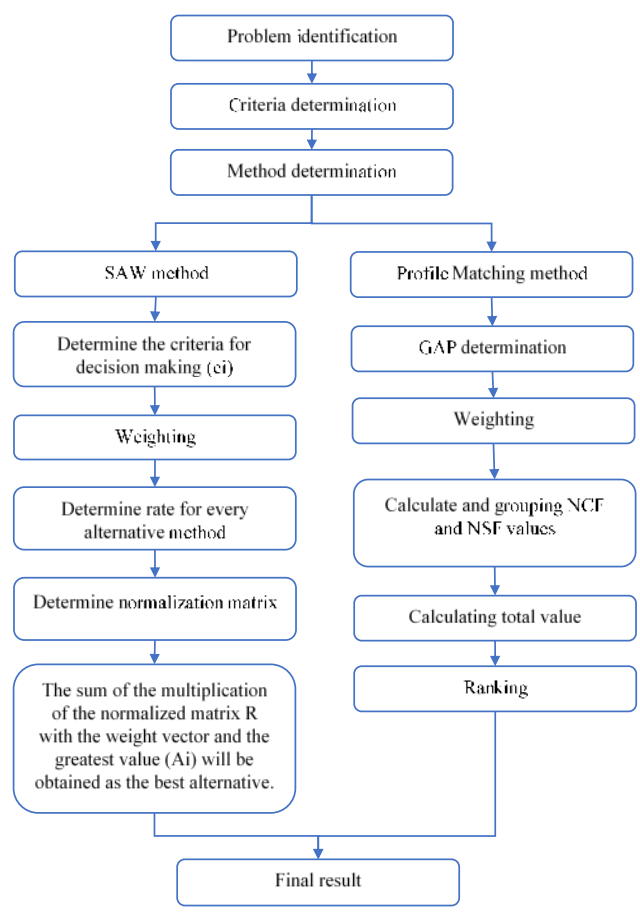

Figure 2. Research method.

\subsection{Data Source}

The data source used as research material is the primary data source. The data required is the result of selection of employee interviews with variables of educational suitability, GPA, which comes from the University, technical abilities, work experience, proficiency test results, biographical information, and data of all applicants who register at one particular company with the same position in accordance with company needs. In this study, the company under study was PT Kayaba Indonesia. This company opens vacancies for 4 positions, namely: Production Foreman \& Warehouse, Foreman Production Planning \& Control, Foreman PCE \& Maintenance, and Supervisor Management System Information. Each vacancy has its own qualifications. In this study, the Foreman position requires qualifications in the form of 
male gender, D3 Department of Mechanical / Electrical / Industrial Engineering, minimum GPA of 2.75, single, maximum age 24 years, while for supervisor positions requires qualifications such as S1 Informatics Engineering Department, minimum GPA 2.75, single, maximum age 26 years.

The data sources obtained are stored in the form of CSV (Comma Separated Values) files. This data will then be loaded through the application, and output in the form of a CSV file as well.

\subsection{System Planning}

The system to be used is a computer with hardware specifications an Intel Core i3 processor, with 4 GB of RAM. The software used is the Ubuntu 18.04 LTS operating system and the Python 3.6 programming language.

In the initial step of the SAW method, the data used is a CSV file that will be inputted through the application. The data will later take values from 5 to 11 criteria selected as a reference. After that, the ranking calculation will be carried out using the SAW method. After the calculation is complete, the system will issue the name and point of the result and can be saved as a CSV file. The system process flow image can be seen in Figure 3.

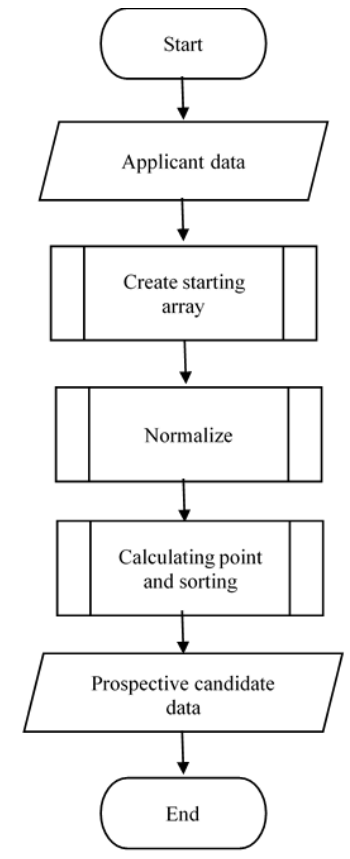

Figure 3. System design with SAW method.

In working on the Profile Matching method applied by the researcher, initially the CSV data is entered by the user then the system will run. When the system is started, a preprocessing process will first run to prepare the data so that it is ready to be processed. Then the calculation process will be carried out using the Profile Matching method to find out which candidate is closest to the predetermined criteria. An overview of the process flow is shown in Figure 4.

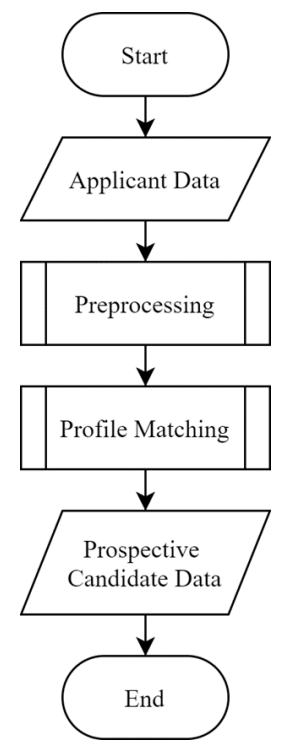

Figure 4. System design with Profile Matching method.

Each candidate will be given a score according to the conditions they have. The process of assigning candidate competency scores in the SAW method is depicted in Figure 5.

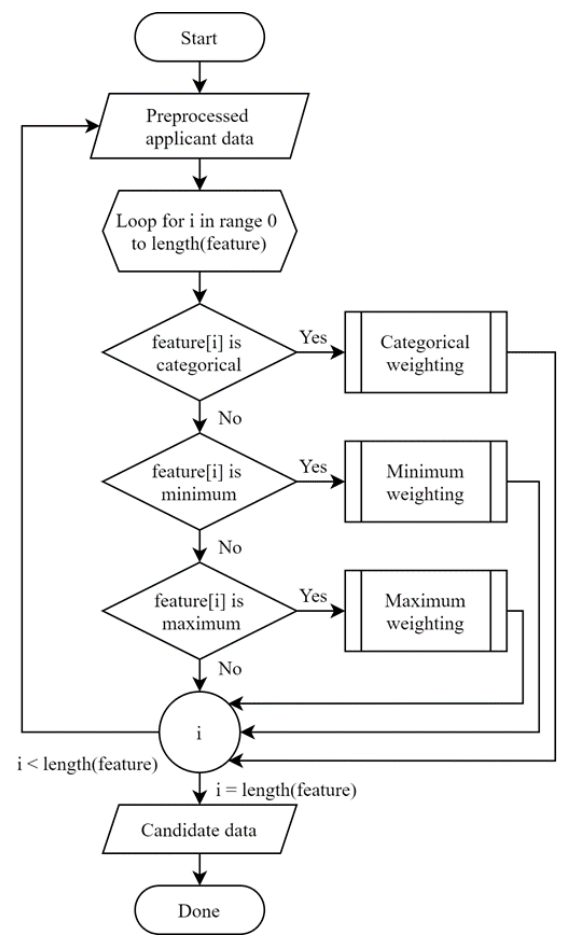

Figure 5. Flowchart of candidate scoring with SAW.

Scoring to each candidate will be divided into 3 ways, the first is to assign scores to features that are categorical. Categorical features include Study Program, Gender, Department, Faculty and Civil Status. Then the candidate value which has a value equal to the ideal profile value that has been determined by the user will get a value of 2 , otherwise it will have a value of 1 . Second is the value of features based on the minimum limit. Features that use a minimum score in determining the desired 
conditions include GPA, TOEFL / TOEIC scores, Height, Year of Graduation, and Year of Entry. Candidates who have a value more than the same as the ideal profile value that has been determined by the user will get a score of 2 , if not then it will have a value of 1 . Then the third is a feature that uses the maximum value in determining the desired conditions, including weight and age. Candidates who have a value less than equal to the ideal profile value defined by the user will get a score of 2 , otherwise it will have a value of 1 .

The calculation process in Profile Matching that used in system development is shown in Figure 6.

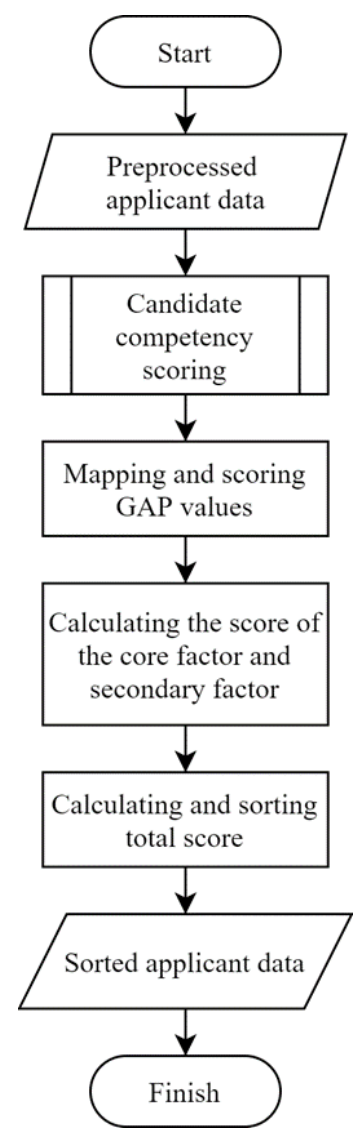

Figure 6. Flowchart of candidate scoring with Profile Matching.

These systems are implemented on computer using programming software with Python programming.

\section{RESULTS AND DISCUSSION}

\subsection{Data Preparation}

The data used are from PT XX's applicants (real name of the company is keep confidentially) with the criteria for the applicant's initial data in the form are full name, position, gender, civil status, place of birth, date of birth, age, height, weight, home address, cellphone number, email, type of English test (TOEIC/TOEFL), TOEIC/TOEFL test score, University, educational stage, year of university entry, year of university graduation, date of graduation trial, semester, GPA, study program, department, faculty, interest, completeness of transcript, completeness of Certificates/SKL, work experience (company, position and length of work), and organizational experience (organization, position, period). In minimizing misunderstandings in university input, normalization is carried out for university features. The number of applicants was 564 applicants with the desired positions, namely: Production Foreman \& Warehouse, Foreman Production Planning \& Control, Foreman PCE \& Maintenance and Supervisor Management Information System. Foreman positions have specific criteria such as male gender, D3 Department of Mechanical / Electrical / Industrial Engineering, minimum GPA of 2.75, single, maximum age 24 years, while supervisor positions require qualifications such as S1 Department of Informatics, minimum GPA of 2.75, Single, maximum age 26 years

\subsection{Results of SAW Method}

The calculating steps to get the scores using the SAW method are as follows (Tables 1-9 are the corresponding results of each steps).

4.2.1. Determine the criteria (Ci) set by PT XX which will be used as a reference in making decisions.

Table 1. Criteria used in the Company

\begin{tabular}{|c|c|c|c|c|}
\hline No & $\begin{array}{c}\text { Criteria } \\
\text { number }\end{array}$ & Criteria & Information & Weight \\
\hline $\mathbf{1}$ & C1 & Benefit & Educational stage & 0.6 \\
\hline $\mathbf{2}$ & C2 & Benefit & Department & 0.5 \\
\hline $\mathbf{3}$ & C3 & Benefit & GPA & 0.4 \\
\hline $\mathbf{4}$ & C4 & Benefit & Civil status & 0.3 \\
\hline $\mathbf{5}$ & C5 & Cost & Age & 0.2 \\
\hline $\mathbf{6}$ & C6 & Benefit & Gender & 0.1 \\
\hline
\end{tabular}

4.2.2. Provide the value of each alternative on each predetermined criterion. Each criterion must be assigned.

Table 2. Weighting of $\mathrm{C} 1$

\begin{tabular}{|c|c|c|c|}
\hline No & User & Educational level & Score \\
\hline $\mathbf{1}$ & User1 & SMK & 1 \\
\hline $\mathbf{2}$ & User2 & D3 & 2 \\
\hline $\mathbf{3}$ & User3 & S1 & 1 \\
\hline $\mathbf{4}$ & User4 & S1 & 1 \\
\hline $\mathbf{5}$ & User5 & D4 & 1 \\
\hline
\end{tabular}

Table 3. Weighting of $\mathrm{C} 2$

\begin{tabular}{|c|c|c|c|c|}
\hline No & User & Department & Category & Score \\
\hline $\mathbf{1}$ & User1 & Accountant & Not available & 0 \\
\hline $\mathbf{2}$ & User2 & $\begin{array}{c}\text { Mechanical } \\
\text { Engineering }\end{array}$ & Available & 1 \\
\hline $\mathbf{3}$ & User3 & $\begin{array}{c}\text { Industrial } \\
\text { Engineering }\end{array}$ & Available & 1 \\
\hline $\mathbf{4}$ & User4 & $\begin{array}{c}\text { Informatics } \\
\text { Electrical } \\
\text { Engineering }\end{array}$ & Not available & 0 \\
\hline $\mathbf{5}$ & User5 & Available & 1 \\
\hline
\end{tabular}

Table 4. Weighting of C3 


\begin{tabular}{|c|c|c|c|}
\hline No & User & GPA & Score \\
\hline $\mathbf{1}$ & User1 & 3 & 3 \\
\hline $\mathbf{2}$ & User2 & 3,05 & 3,05 \\
\hline $\mathbf{3}$ & User3 & 3,32 & 3,32 \\
\hline $\mathbf{4}$ & User4 & 3,19 & 3,19 \\
\hline $\mathbf{5}$ & User5 & 3,29 & 3,29 \\
\hline
\end{tabular}

Table 5. Weighting of C4

\begin{tabular}{|c|c|c|c|}
\hline No & User & Civil status & Score \\
\hline $\mathbf{1}$ & User1 & Single & 1 \\
\hline $\mathbf{2}$ & User2 & Single & 1 \\
\hline $\mathbf{3}$ & User3 & Single & 1 \\
\hline $\mathbf{4}$ & User4 & Single & 1 \\
\hline $\mathbf{5}$ & User5 & Single & 1 \\
\hline
\end{tabular}

Table 6. Weighting of C5

\begin{tabular}{|c|c|c|c|}
\hline No & User & Birth date & Score \\
\hline $\mathbf{1}$ & User1 & $18 / 11 / 2001$ & 18 \\
\hline $\mathbf{2}$ & User2 & $22 / 03 / 1998$ & 21 \\
\hline $\mathbf{3}$ & User3 & $01 / 01 / 1994$ & 26 \\
\hline $\mathbf{4}$ & User4 & $18 / 09 / 1996$ & 23 \\
\hline $\mathbf{5}$ & User5 & $13 / 09 / 1996$ & 23 \\
\hline
\end{tabular}

Table 7. Weighting of C6

\begin{tabular}{|c|c|c|c|}
\hline No & User & Gender & Score \\
\hline $\mathbf{1}$ & User1 & Woman & 0 \\
\hline $\mathbf{2}$ & User2 & Man & 1 \\
\hline $\mathbf{3}$ & User3 & Man & 1 \\
\hline $\mathbf{4}$ & User4 & Man & 1 \\
\hline $\mathbf{5}$ & User5 & Man & 1 \\
\hline
\end{tabular}

\subsubsection{Determine the suitability rating of each alternative on} each criterion

Table 8. Table of Ratings in each Criterion

\begin{tabular}{|c|c|c|c|c|c|c|c|}
\hline \multirow{2}{*}{ No } & \multirow{2}{*}{ User } & \multicolumn{6}{|c|}{ Criterion } \\
\cline { 3 - 8 } & & C1 & C2 & C3 & C4 & C5 & C6 \\
\hline $\mathbf{1}$ & User1 & 0,5 & 0 & 0,90361 & 1 & 1 & 0 \\
\hline $\mathbf{2}$ & User2 & 1 & 1 & 0,91867 & 1 & 0,857143 & 1 \\
\hline $\mathbf{3}$ & User3 & 0,5 & 1 & 1 & 1 & 0,692308 & 1 \\
\hline $\mathbf{4}$ & User4 & 0,5 & 0 & 0,96084 & 1 & 0,782609 & 1 \\
\hline $\mathbf{5}$ & User5 & 0,5 & 1 & 0,99096 & 1 & 0,782609 & 1 \\
\hline
\end{tabular}

4.2.4. Decision matrix based on criteria (Ci), then performed the matrix normalization

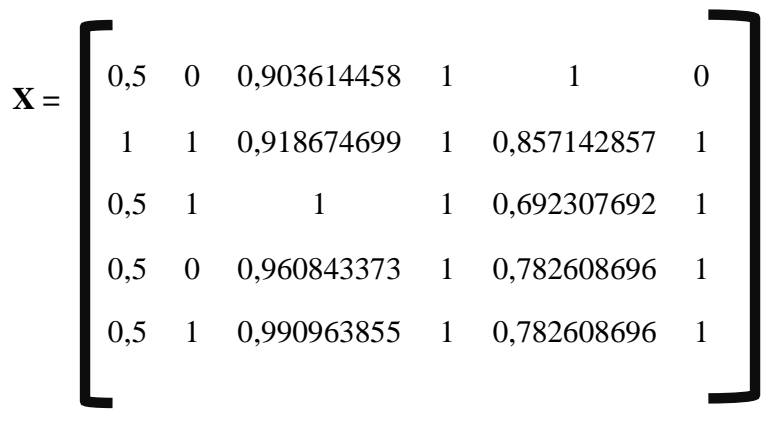

\subsubsection{Normalization in each criterion}

Criteria of level, including benefit:

$\mathrm{R} 1.1=\frac{1}{2}=0.5$
$\mathrm{R} 1.2=\frac{2}{2}=1$
$\mathrm{R} 1.3=\frac{1}{2}==0.5$
$\mathrm{R} 1.4=\frac{1}{2}==0.5$
$\mathrm{R} 1.5=\frac{1}{2}==0.5$

Criteria of GPA, including benefit

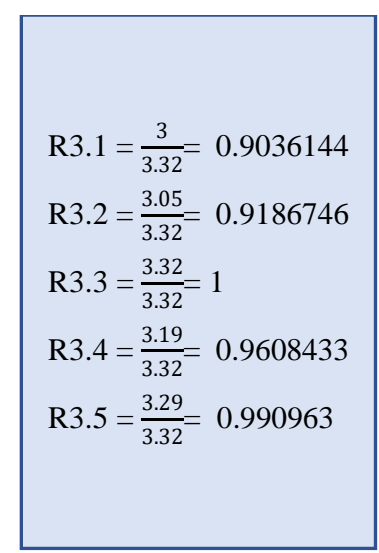

Criteria of Age, including benefit:

$$
\begin{aligned}
& \mathrm{R} 5 \cdot 1=\frac{18}{18}=1 \\
& \mathrm{R} 5 \cdot 2=\frac{18}{21}=0,85714285 \\
& \mathrm{R} 5 \cdot 3=\frac{18}{26}=0,69230769 \\
& \mathrm{R} 5 \cdot 4=\frac{18}{23}=0,78260869 \\
& \mathrm{R} 5 \cdot 5=\frac{18}{23}=0,7826087
\end{aligned}
$$

Criteria of major, including benefit:

$\mathrm{R} 2.1=\frac{0}{1}=0$
$\mathrm{R} 2.2=\frac{1}{1}=1$
$\mathrm{R} 2.3=\frac{1}{1}=1$
$\mathrm{R} 2.4=\frac{0}{1}=0$
$\mathrm{R} 2.5=\frac{1}{1}=1$

Criteria of status, including benefit

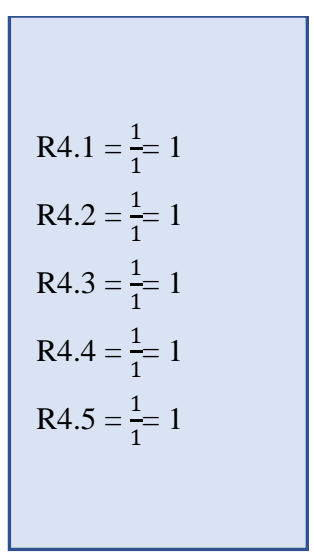

Criteria of sex, including benefit

$$
\begin{aligned}
& \mathrm{R} 6.1=\frac{0}{1}=0 \\
& \mathrm{R} 6.2=\frac{1}{1}=1 \\
& \mathrm{R} 6.3=\frac{1}{1}=1 \\
& \mathrm{R} 6.4=\frac{1}{1}=1 \\
& \mathrm{R} 6.5=\frac{1}{1}=1
\end{aligned}
$$


Table 9. Final Result of SAW Method

\begin{tabular}{|c|c|c|c|c|c|c|c|c|}
\hline \multirow{3}{*}{ No } & \multirow{3}{*}{$\begin{array}{l}\text { Alterna } \\
\text { tive }\end{array}$} & \multicolumn{6}{|c|}{ Criterion } & \multirow{3}{*}{ Sum } \\
\hline & & \multicolumn{4}{|c|}{ Benefit } & Cost & Benefit & \\
\hline & & C1 & $\mathrm{C} 2$ & C3 & $\mathrm{C} 4$ & C5 & C6 & \\
\hline 1 & User 2 & 0,6 & 0,5 & 0,36746988 & 0,3 & 0,171428571 & 0,1 & 2,038898451 \\
\hline 2 & User5 & 0,3 & 0,5 & 0,396385542 & 0,3 & 0,156521739 & 0,1 & 1,752907281 \\
\hline 3 & User3 & 0,3 & 0,5 & 0,4 & 0,3 & 0,138461538 & 0,1 & 1,738461538 \\
\hline 4 & User4 & 0,3 & 0 & 0,384337349 & 0,3 & 0,156521739 & 0,1 & 1,240859089 \\
\hline 5 & User1 & 0,3 & 0 & 0,361445783 & 0,3 & 0,2 & 0 & 1,161445783 \\
\hline
\end{tabular}

From 564 initial data, researchers processed by using the SAW method and filtered 144 data of prospective employees. From the 144 data of prospective employees, the researchers got some recommendations based on the highest ranking (rank 1- 5) of these prospective employees, namely:

1. User 2 with total points 2.038898451

2. User 5 with total points 1.752907281

3. User 3 with total points 1.738461538

4. User 4 with total points 1.240859089

5. User 1 with total points 1.161445783

The data will be tested for the accuracy and specificity by using the Confusion Matrix method. The results of the Confusion Matrix test are given in Table 10.

Table 10. Confusion Matrix SAW Table

\begin{tabular}{|c|c|c|}
\hline \multicolumn{2}{|c|}{ Initial Data } & $\mathbf{5 6 4}$ \\
\hline \multirow{2}{*}{ Result } & SAW & 144 \\
\hline \multirow{2}{*}{$\begin{array}{c}\text { Confusio } \\
\text { n Matrix }\end{array}$} & TP & 126 \\
\cline { 2 - 3 } & FP & 18 \\
\cline { 2 - 3 } & TN & 12 \\
\hline \multirow{2}{*}{ Accuracy } & 408 \\
\hline Precision & $94.7 \%$ \\
\hline \multicolumn{2}{|c|}{ Recall } & $87.5 \%$ \\
\hline \multicolumn{2}{|c|}{ F - Measure } & $91.3 \%$ \\
\hline Specificity & $89.4 \%$ \\
\hline
\end{tabular}

From the table 10, there were 564 initial participants and screened into 154 participants by using the SAW method. It was shown that the SAW method had an accuracy of $94.7 \%$, a precision of $87.5 \%$, a recall of $91.3 \%$, and an F-Measure of $89.4 \%$.

The accuracy of $94.7 \%$ in the SAW method is greater than the research hypothesis which stated that the accuracy rate of SAW method was $80-90 \%$. This indicates that the SAW method has a very good level of accuracy to be applied in the new employee candidate selection system. This high level of accuracy is also supported by a high number of high precision $(87.5 \%)$. This shows that the SAW method is very specific to be used in selecting employee candidate recommendations according to predetermined criteria. This is supported by the high recall rate of $91 \%$ and a F-Measure value of $89.4 \%$.

\subsection{Result of Profile Matching Method}

The calculating steps to get the scores using the SAW method are as follows (Tables 11-20 are the corresponding results of each steps).

\subsubsection{GAP mapping}

Table 11. C1 GAP calculation

\begin{tabular}{|c|c|c|c|}
\hline \multirow{2}{*}{ Alternative } & \multicolumn{3}{|c|}{ C1 (Age) } \\
\cline { 2 - 4 } & $\begin{array}{c}\text { Employee } \\
\text { profile }\end{array}$ & $\begin{array}{c}\text { Position } \\
\text { profile }\end{array}$ & GAP \\
\hline User1 & 24 & 24 & 0 \\
\hline User2 & 26 & 24 & -2 \\
\hline User3 & 24 & 24 & 0 \\
\hline User4 & 24 & 24 & 0 \\
\hline User5 & 23 & 24 & 1 \\
\hline
\end{tabular}

Table 12. C2 GAP calculation

\begin{tabular}{|c|c|c|c|}
\hline \multirow{2}{*}{ Alternative } & \multicolumn{3}{|c|}{ C2 (Status) } \\
\cline { 2 - 4 } & $\begin{array}{c}\text { Employee } \\
\text { profile }\end{array}$ & $\begin{array}{c}\text { Position } \\
\text { profile }\end{array}$ & GAP \\
\hline User1 & Single & Single & 0 \\
\hline User2 & Single & Single & 0 \\
\hline User3 & Single & Single & 0 \\
\hline User4 & Single & Single & 0 \\
\hline User5 & Single & Single & 0 \\
\hline
\end{tabular}

Table 13. C3 GAP calculation

\begin{tabular}{|c|c|c|c|}
\hline \multirow{2}{*}{ Alternative } & \multicolumn{3}{|c|}{ C3 (Education) } \\
\cline { 2 - 4 } & $\begin{array}{c}\text { Employee } \\
\text { profile }\end{array}$ & $\begin{array}{c}\text { Position } \\
\text { profile }\end{array}$ & $\begin{array}{c}\text { Employee } \\
\text { profile }\end{array}$ \\
\hline User1 & SMK & User1 & SMK \\
\hline User2 & D3 & User2 & D3 \\
\hline User3 & S1 & User3 & S1 \\
\hline User4 & S1 & User4 & S1 \\
\hline User5 & D4 & User5 & D4 \\
\hline
\end{tabular}

Table 14. C4 GAP calculation

\begin{tabular}{|c|c|l|c|}
\hline \multirow{2}{*}{ Alternative } & \multicolumn{3}{|c|}{ C4 (Major) } \\
\cline { 2 - 4 } & Employee profile & Position profile & GAP \\
\hline User1 & Business & Mechanical Eng. & 1 \\
\hline User2 & Mechanical Eng. & Mechanical Eng. & 0 \\
\hline User3 & Industrial Eng. & Mechanical Eng. & 1 \\
\hline User4 & Informatics & Mechanical Eng. & 1 \\
\hline User5 & $\begin{array}{c}\text { Telecommunication } \\
\text { Eng. }\end{array}$ & Mechanical Eng. & 1 \\
\hline
\end{tabular}


Table 15. C5 GAP calculation

\begin{tabular}{|c|c|c|c|}
\hline \multirow{2}{*}{ Alternative } & \multicolumn{3}{|c|}{ C5 (GPA) } \\
\cline { 2 - 4 } & $\begin{array}{c}\text { Employee } \\
\text { profile }\end{array}$ & $\begin{array}{c}\text { Position } \\
\text { profile }\end{array}$ & GAP \\
\hline User1 & 2,82 & 3 & 0 \\
\hline User2 & 3,26 & 3,05 & 0 \\
\hline User3 & 3,33 & 3,32 & 0 \\
\hline User4 & 3,16 & 3,19 & 0 \\
\hline User5 & 3,46 & 3,29 & 0 \\
\hline
\end{tabular}

Table 16. C6 GAP calculation

\begin{tabular}{|c|c|c|c|}
\hline \multirow{2}{*}{ Alternative } & \multicolumn{3}{|c|}{ C6 (Gender) } \\
\cline { 2 - 4 } & Employee profile & Position profile & GAP \\
\hline User1 & Woman & Man & 1 \\
\hline User2 & Man & Man & 0 \\
\hline User3 & Man & Man & 0 \\
\hline User4 & Man & Man & 0 \\
\hline User5 & Man & Man & 0 \\
\hline
\end{tabular}

\subsubsection{Weighting}

Table 17. Weighting results

\begin{tabular}{|c|c|c|c|c|c|c|}
\hline \multirow{2}{*}{ Alternative } & \multicolumn{7}{|c|}{ Weight } \\
\cline { 2 - 7 } & C1 & C2 & C3 & C4 & C5 & C6 \\
\hline User1 & 2 & 2 & 1 & 1 & 2 & 1 \\
\hline User2 & 1 & 2 & 2 & 2 & 2 & 2 \\
\hline User3 & 2 & 2 & 1 & 1 & 2 & 2 \\
\hline User4 & 2 & 2 & 1 & 1 & 2 & 2 \\
\hline User5 & 2 & 2 & 1 & 1 & 2 & 2 \\
\hline
\end{tabular}

\subsubsection{Calculating and grouping of core and secondary factor}

Table 17. Grouping of core and secondary factor

\begin{tabular}{|c|c|c|c|}
\hline No & Category & Information & Factor \\
\hline $\mathbf{1}$ & C1 & Age & Secondary \\
\hline $\mathbf{2}$ & C2 & Graduation year & Core \\
\hline $\mathbf{3}$ & C3 & Education stage & Core \\
\hline $\mathbf{4}$ & C4 & Major & Core \\
\hline $\mathbf{5}$ & C5 & GPA & Core \\
\hline
\end{tabular}

\begin{tabular}{|l|l|l|l}
6 & C6 & Gender & Core \\
\hline
\end{tabular}

Table 18. Core and secondary factor calculation

\begin{tabular}{|c|c|c|c|c|c|c|}
\hline \multirow{2}{*}{ Alternative } & \multicolumn{7}{|c|}{ Weight } \\
\cline { 2 - 7 } & C1 & C2 & C3 & C4 & C5 & C6 \\
\hline User1 & 0,4 & 1,6 & 0,8 & 0,8 & 1,6 & 0,8 \\
\hline User2 & 0,2 & 1,6 & 1,6 & 1,6 & 1,6 & 1,6 \\
\hline User3 & 0,4 & 1,6 & 0,8 & 0,8 & 1,6 & 1,6 \\
\hline User4 & 0,4 & 1,6 & 0,8 & 0,8 & 1,6 & 1,6 \\
\hline User5 & 0,4 & 1,6 & 0,8 & 0,8 & 1,6 & 1,6 \\
\hline Core factor 80\% secondary factor $20 \%$ & & & \\
\hline \multicolumn{7}{|l|}{} \\
\hline
\end{tabular}

\subsubsection{Total calculation of score}

Table 19. Total calculation score

\begin{tabular}{|c|c|c|c|c|}
\hline User & NSF & NCF & NCI & Rank \\
\hline User1 & 0,4 & 1,4 & 1,8 & 5 \\
\hline User2 & 0,2 & 2 & 2,2 & 1 \\
\hline User3 & 0,4 & 1,6 & 2 & 3 \\
\hline User4 & 0,4 & 1,6 & 2 & 4 \\
\hline User5 & 0,4 & 1,6 & 2 & 2 \\
\hline
\end{tabular}

\subsubsection{Final ranking result}

Table 20. Total rank

\begin{tabular}{|c|c|c|c|c|}
\hline User & NSF & NCF & NCI & Rank \\
\hline User2 & 0,2 & 2 & 2,2 & 1 \\
\hline User5 & 0,4 & 1,6 & 2 & 2 \\
\hline User3 & 0,4 & 1,6 & 2 & 3 \\
\hline User4 & 0,4 & 1,6 & 2 & 4 \\
\hline User1 & 0,4 & 1,4 & 1,8 & 5 \\
\hline
\end{tabular}

From the initial 564 data, after the Profile Matching Method was carried out, the filtered data was obtained for 140 prospective employees. From the 140 data on prospective employees, recommendations for prospective employees are obtained based on the ranking of the highest. Prospective employees include:

1. User 2 with total points 2.8

2. User 5 with total points 2.7

3. User 3 with total points 2.7

4. User 4 with total points 2.7

5. User 1 with total points 2

The data will be tested for accuracy and specificity using the Confusion Matrix method. The results of the Confusion Matrix test are given in Table 21.

Table 21. Confusion Matrix of Profile Matching 


\begin{tabular}{|c|c|c|}
\hline \multicolumn{2}{|c|}{ Initial Data } & 564 \\
\hline Result & PM & 140 \\
\hline \multirow{4}{*}{$\begin{array}{c}\text { Confusion } \\
\text { Matrix }\end{array}$} & TP & 114 \\
\hline & FP & 26 \\
\hline & FN & 26 \\
\hline & $\mathrm{TN}$ & 377 \\
\hline \multicolumn{2}{|c|}{ Accuracy } & $90,4 \%$ \\
\hline \multicolumn{2}{|c|}{ Precision } & $81,4 \%$ \\
\hline \multicolumn{2}{|c|}{ Recall } & $81,4 \%$ \\
\hline \multicolumn{2}{|c|}{ F - Measure } & $81,4 \%$ \\
\hline \multicolumn{2}{|c|}{ Specificity } & $93,5 \%$ \\
\hline
\end{tabular}

\section{CONCLUSION}

From the research that had been done, it could be concluded that:

1. The Simple Addictive Weighting (SAW) Method and the Profile Matching Method are proven to have the equal level of accuracy, namely $80-90 \%$ in the process of recruiting new employees

2. The Simple Addictive Weighting (SAW) Method and the Profile Matching Method are proven to have the equal level of Sensitivity to recall, namely $80-90 \%$ in the process of recruiting new employees.

3. The Simple Addictive Weighting (SAW) Method and the Profile Matching Method are proven to have the equal level of Precision, namely $80-90 \%$ in the process of recruiting new employees.

\section{REFERENCES}

[1] S. Abadi, F. Latifah and K. Kunci, "Sistem Pendukung Keputusan \& Kinerja Karyawan Pada Perusahaan Menggunakan Metode Simple Additive Weighting," Technology Acceptance Model, vol. 6, no. 4312, p. 37, 2016.

[2] Sunarti and S. Jenie, "Perbandingan Metode SAW dan Profile Matching pada Pemilihan Rumah Tinggal Studi Kasus: Perumahan Depok," INTENSIF, vol. 2, no. 2580409X, 2018.

[3] S. S. Sundari and Y. F. Taufik, "Pegawai Baru dengan menggunakan Metode Simple Additive Weighting (SAW)," Sisfotenika, vol. 4, pp. 140-151, 2014.

[4] Kusrini, Konsep dan Aplikasi Sistem Pendukung Keputusan, C.V. Andi Offset, 2007.

[5] M. I. T., A. P. N. and Sulton, "Sistem Pendukung Keputusan Seleksi Karyawan Menggunakan Metode Simple Additive Weighting Pada PT. Philips Seafood Indonesia," Jurnal Informatika Merdeka Pasuruan, vol. 1, no. 2503-1945, p. 3, 2016.

[6] N. Nuraeni, "Penerapan Metode Simple Additive Weigting (SAW) Dalam Seleksi Calon Karyawan," SWABUMI, vol. 6, no. 2355-990X, pp. 63-71, 2018.
[7] D. W. Syah, E. Santoso and R. S. Perdana, "Sistem Pendukung Keputusan Pengurutan Berdasarkan Jenis Suara Anggota Baru Divisi Paduan Suara BIOS Menggunakan Metode Profile Matching (Studi Kasus : Logicio Choir FILKOM)," Jurnal Pengembangan Teknologi Informasi dan Ilmu Komputer, vol. 1(12), no. ISSN 2548-964X, pp. 1678-1686, 2017.

[8] K. Giovani, R. Rekyan and M. A. F, "Sistem Pendukung Keputusan Seleksi Tenaga Pengajar Musik Menggunakan Metode Profile Matching," Infortech, vol. 7(13), no. 31158170, 2015.

[9] E. Turban, R. Sharda and D. Delen, Decision Support and Business Intelligence Systems, Pearson Education Inc, 2011.

[10] S. Kusumadewi, S. Hartati, A. Harjoko and R. Wardoyo, Fuzzy MultiAtribute Decision Making (MADM), Yogyakarta: Graha Ilmu, 2006.

[11] A. Sudarmadi and E. Santoso, "Sistem Pendukung Keputusan Pemilihan Personel Homeband Universitas Brawijaya Menggunakan Metode Profile Matching," SISFOTENIKA, vol. 1(12), pp. 1788-1796, 2017. 